\title{
1. Before the new era: the story of the FCPA and its early enforcement
}

In a book titled 'The Foreign Corrupt Practices Act in a New Era', it may seem odd to begin by rewinding the clock back to a different era. However, to best understand and appreciate the FCPA's new era, it is first necessary to understand and appreciate why the FCPA became a law in 1977. As with most new laws, the FCPA did not appear out of thin air. Rather, real events and real policy reasons motivated Congress to act and pass the FCPA, and this chapter begins by telling the FCPA's story.

In this chapter, you will also be introduced to early FCPA enforcement and understand how the FCPA matured through its 1988 and 1998 amendments into its modern form.

\section{A. THE IMPORTANCE OF THE FCPA's LEGISLATIVE HISTORY}

Why Congress enacted the FCPA and what conduct Congress sought to capture by the law are topics that are often overlooked in this new era. However, the FCPA's legislative history is important and the Supreme Court has noted that the legislative history of a statute is frequently the most fruitful source of instruction as to its proper interpretation. ${ }^{1}$ In the FCPA context, an appellate court explained:

Our task in interpreting the FCPA 'is to construe the language so as to give effect to the intent of Congress.' To do so, we look primarily to the language of the statute and secondarily to its legislative history, which includes 'the purpose the original enactment served, the discussion of statutory meaning in committee reports ... and the remarks in debate preceding passage.' ${ }^{2}$

Another appellate court noted: 'As the [FCPA's] language itself is amenable to more than one reasonable interpretation, it is ambiguous as a matter of law. We turn therefore to legislative history in our effort to ascertain Congress's true intentions.' ${ }^{3}$ 
Indeed, a statute's legislative history is all the more important when it contains vague and ambiguous terms and it has been noted that 'vagueness and ambiguity are the DNA of the FCPA. ${ }^{4}$ Although you will learn that judicial scrutiny of FCPA enforcement is rare, in the few instances in which the FCPA has been subjected to judicial scrutiny judges have frequently found that the FCPA's elements are ambiguous and thus resorted to the legislative history. ${ }^{5}$ Sources of FCPA legislative history that judges have consulted include committee reports; statements by legislators in debates, particularly those sponsoring legislation; testimony at congressional hearings; facts and circumstances Congress was aware of when considering the law; and bills considered but rejected by Congress. ${ }^{6}$

Understanding the FCPA's legislative history is thus not merely an interesting history lesson or an academic exercise. Rather, the rule of law demands an analysis of the legislative history in giving meaning to the FCPA. For this reason, Chapter 1 begins by highlighting the FCPA's extensive legislative history.

\section{B. THE STORY OF THE FCPA}

In the mid-1970s, Congress journeyed into uncharted territory. After more than two years of investigation, deliberation and consideration, what emerged in 1977 was the FCPA. The FCPA was a pioneering statute and the first law in the world governing domestic business conduct with foreign government officials in foreign markets.

In this section, the FCPA's story is told largely through original voices of actual participants who shaped the pioneering and controversial law signed by President Jimmy Carter in 1977.

Among other issues, you will learn in this section:

- how the foreign corporate payments problem was discovered, specific events that prompted congressional concern, and the policy ramifications of those events - most notably foreign policy - which motivated Congress to act;

- that upon discovery of the foreign corporate payments problem, Congress's first task was to determine if the payments were adequately captured by existing law;

- how seeking new legislative remedies to the foreign corporate payments problem was far from a consensus view of the U.S. government and the divergent views as to a solution; 
- how Congress sought to address the foreign corporate payments problem from a variety of angles and the resulting two main competing legislative responses to the problem - a disclosure approach as to a broad category of payments and a criminalization approach as to a narrow category of payments; and

- how the FCPA was intended to be a limited statute in that even though Congress learned of a variety of foreign corporate payments to a variety of recipients and for a variety of reasons, Congress accepted in passing the FCPA to capture only a narrow category of such payments.

\section{The Foreign Payments Problem}

Discovery of the foreign corporate payments problem in the mid-1970s resulted from a combination of work by the Office of the Watergate Special Prosecutor, including related follow-up work and investigations by the SEC, and Senator Frank Church's Subcommittee on Multinational Corporations (Church Committee).

The Report of the SEC on Questionable and Illegal Corporate Payments and Practices (SEC Report) stated:

In 1973, as a result of the work of the [Watergate Prosecutor] several corporations and executive officers were charged with using corporate funds for illegal domestic political contributions. The Commission recognized that these activities involved matters of possible significance to public investors, the nondisclosure of which might entail violations of the federal securities laws. ... The Commission's inquiry into the circumstances surrounding alleged illegal political campaign contributions revealed that violations of the federal securities laws had indeed occurred. The staff discovered falsifications of corporate financial records, designed to disguise or conceal the source and application of corporate funds misused for illegal purposes, as well as the existence of secret 'slush funds' disbursed outside the normal financial accountability system. These secret funds were used for a number of purposes, including in some instances, questionable or illegal foreign payments. $^{7}$

Along with the SEC's work, the Church Committee also helped shine a light on questionable foreign corporate payments. In 1975, the Church Committee held the first of several hearings generally dealing with U.S. corporate political contributions to foreign governments. Senator Church opened the hearings as follows:

In the course of the Watergate Committee hearings and the investigation by the Special Prosecutor, it became apparent that major American corporations 
had made illegal political contributions in the United States. More recently, the [SEC] has revealed that several multinational corporations had failed to report to their shareholders millions of dollars of offshore payments in violation of the Securities laws of the United States. ... The [SEC] is understandably concerned that the disclosure requirements of U.S. laws are complied with. This subcommittee is concerned with the foreign policy consequences of these payments by U.S.-based multinational corporations. This is not a pleasant or easy subject for the corporations involved or U.S. Government officials to discuss in a public forum. This subcommittee deliberated long and hard as to whether it should pursue this matter, and, if so, in what fashion. It decided by a unanimous vote to initiate this investigation and to do so in open public hearings. For what we are concerned with is not a question of private or public morality. What concerns us here is a major issue of foreign policy for the United States. ${ }^{8}$

The Church Committee held separate hearings regarding Gulf Oil, Northrop, Mobil Oil, and Lockheed. Each of these corporations was the subject of allegations, or had already made admissions, concerning questionable payments made directly or indirectly to foreign government officials or foreign political parties. For instance, Gulf Oil principally involved contributions to the political campaign of the President of the Republic of Korea. Northrop principally involved payments to a Saudi Arabian general. Exxon and Mobil Oil principally involved contributions to Italian political parties. Lockheed principally involved payments to Japanese Prime Minister Tanaka, Prince Bernhard (the Inspector General of the Dutch Armed Forces and the husband of Queen Juliana of the Netherlands), and Italian political parties. In addition, foreign payments by United Brands and Ashland Oil also concerned Congress. United Brands principally involved payments to Oswaldo Lopez Arellano, the President of Honduras and Ashland Oil principally involved payments to Albert Bernard Bongo, the President of Gabon.

Even though the problematic corporate payments unearthed in the mid-1970s were extensive and significant, efforts were made to place the conduct in the proper context. For instance, a Department of the Treasury official stated during a 1976 House hearing:

Although I do not wish to minimize the seriousness of the problem, the situation can be put in the proper light by noting that the approximately 200 firms [the subject of questionable payment inquiries] come from a total of more than 9,000 that regularly file with the Commission. ... Only a relatively few firms appear to have engaged in making questionable payments abroad. The vast bulk of our firms conduct their businesses ethically and completely in accord with the laws of the United States. We should not let the activities of a minority of U.S. firms operating abroad cast doubts on the nature or conduct of U.S. business generally. ${ }^{9}$ 
Even as to the companies implicated in the questionable conduct, the SEC Report noted that '[t]he conduct reported varies significantly, and the companies included can by no means universally be characterized as wrongdoers.' In a 1975 speech included in the legislative record, the SEC Chairman stated:

All improper foreign payments, of course, are not big bribes. Many of them are small and in the foreign community where made possibly not really regarded as improper at all. If the local plant manager in a foreign country has to slip a weekly mordita of modest amount to the postman in order to get regular mail deliveries, or to the customs inspector, the fire inspector or the tax collector, is that something for us to get excited about? In our public statements, individual members of the Commission have said no, at least where these payments conform to custom and usage. Similar payments, at the local level, anyway, are not unknown in the United States. ${ }^{10}$

\section{Likewise, the SEC Chairman stated:}

It is, of course, important ... to make distinctions among these companies. It is quite true that in some cases the payments were cynically and arrogantly made by top corporate officials who knew they were acting contrary to existing laws and regulations and without the authority of their board of directors. Indeed, many went to great lengths to conceal their conduct from the outside auditors, outside directors, and of course, the shareholders. But it is equally true that in a very large number of cases, the sums of money that have been involved are relatively small and were made by persons at a much lower level of management who went to great pains to conceal their own activities from their superiors. Unfortunately, the distinctions between these different types of corporate misconduct have not been made sufficiently clear to the public. ${ }^{11}$

Indeed, some resented that U.S. companies were being unjustly pilloried for a worldwide problem. Senator Abraham Ribicoff was the most passionate in his views. During a 1975 Senate hearing in the early stage of Congress's investigation of the problem, he described a recent trip to world capitals to discuss various trade issues and stated:

What disturbed me as I traveled around the world was the realization that American business was being internationally blamed for activities which are very obvious to me were a very common practice throughout the entire world. [...] And I sort of resented American companies being pilloried for what was a common practice throughout the world. ... American corporations have been pilloried on the front pages and the television of not only the United States but throughout the entire world. And the world and the American people have been given to believe that American corporations are the only malefactors of this practice. And, yet, anybody who knows what is going on 
worldwide knows this is a worldwide phenomenon; that business houses and business corporations in every nation of the world are paying under the table and are guilty of bribes but none of them paint them this way. ${ }^{12}$

Foreign policy was the primary policy concern from the discovered foreign corporate payments which motivated Congress to act. Representative Robert Nix, who chaired a series of House hearings in 1975 as to the foreign corporate payments, stated:

There has been a negative impact on our foreign policy already because of these revelations. Peru has expropriated property of the Gulf Corp. in that country. Costa Rica is considering expropriation legislation and other countries in Latin America may be considering such steps. The interference in democratic elections with corporate gifts undermines everything we are trying to do as a leader of the free world ... In Italy the Communist party is using the fact of multinational bribery in Italy against the political friends of the United States. ${ }^{13}$

In chairing another 1975 Senate hearing regarding the foreign payments, Senator Church again expressed that foreign policy was his chief concern:

There is also little doubt that widespread corruption serves to undermine those moderate democratic and pro-free-enterprise governments which the United States has traditionally sought to foster and support. Several oil companies testified before the subcommittee that they had made huge political contributions in Italy and Korea, for example. They claimed to be supporting the democratic forces who are friendly to foreign capital in those countries, but in fact, they were subverting the basic democratic processes of those two countries by making illegal contributions and were, at the same time, providing the radical left with its strongest election issue. The large and steady gains made by the Italian Communist Party in recent elections are due in no small part to the fact that it is believed to be the only non-corrupt political force in the country, while the other parties are seen as the handmaidens of foreign and domestic financial interests. So that while bribes and kickbacks may bolster sales in the short run, the open participation of American firms in such practices can, in the long run, only serve to discredit them and the United States. Ultimately, they create the conditions which bring to power political forces that are no friends of ours ... I have focused on the foreign policy aspects of this issue because that is the chief concern of my subcommittee. ${ }^{14}$

\section{Senator Church further stated:}

These very practices have extremely serious consequences both for the conduct of U.S. foreign policy and the reception U.S. business receives 
abroad. U.S.-based corporations should not be allowed to weaken a friendly government through bribery and corruption while the United States is relying on that government as a stable sure friend in supporting our policies. U.S.-based corporations should not be supporting political factions antithetical to those supported by the U.S. Government. Nor do we want, as was revealed in Multinational Subcommittee hearings, the defense priorities of our allies distorted by corporate bribery.

Further, when these payments become known, and they will and do, whether it be through revelations by Senate subcommittees or through the common knowledge that leads to revolution and the downfall of such governments ..., the repercussions are often international and the foreign policy implications for the United States severe. Payments by Lockheed alone may very well advance the communists in Italy. In Japan, a mainstay of our foreign policy in the Far East, the government is reeling as a consequence of payments by Lockheed. Inquiries have begun in many other countries. The Communist bloc chortles with glee at the sight of corrupt capitalism. ${ }^{15}$

Representative Solarz, who emerged as a leader in the House as to the foreign payments problem, stated during a House hearing:

What is at stake is much more than the individual interests of corporations which are competing for a share of foreign markets. What is in fact at stake is the foreign policy and national interest of the United States. It is clearly in our interest to put a stop to these pernicious practices. [...] We simply cannot permit activity which so damages U.S. foreign policy. ${ }^{16}$

Even though foreign policy was the primary policy concern motivating Congress to act, it was not the sole concern. Congressional motivation was also sparked by a post-Watergate morality, economic perceptions including a sense that prohibiting foreign corporate payments would give U.S. companies a comparative advantage and actually help companies resist foreign payment demands, as well as global leadership.

Representative Solarz stated during a 1975 House hearing:

Simple business ethics would seem to dictate the standards on which firms would conduct their affairs, and it is truly a sad commentary that the excuse put forward by most of the corporations is that other nations engage in bribery and massive political contributions as well. The conduct of commercial operations by foreign nations in a morally shabby manner is no excuse for American citizens to engage in such scandalous activities as well. To the extent that international bribery is characteristic of business dealings in other parts of the world, the participation of American firms in it warrants prompt and effective elimination. ... What is at stake here is really, in a number of significant respects, the reputation of our own country, and I think that we have an obligation to set a standard of honesty and integrity in our business 
dealings not only at home but also abroad which will be a beacon for the light of integrity for the rest of the world. ${ }^{17}$

Even though many of the foreign corporate payments presented a moral quandary, not all participants in the legislative debate were prepared to offer a firm response. For instance, during a Senate hearing in 1975 focused on the Lockheed scandal, Senator John Tower stated: 'A central question is raised here and that is, is it morally right for an American company to operate within the mores and folkways of the society in which they are trying to do business? I'm not prepared to give a snap answer to that myself.' ${ }^{18}$

The above statement hinted at the many difficult and complex issues Congress encountered in addressing the foreign corporate payments problem as well as the many difficult and complex issues that remain in this new era.

As to economic perceptions being a factor motivating Congress to act, Senator Proxmire stated:

Consider the argument against corporate bribery as a policy. The payoff may cost a lot of money and still not work. You are paying off people who are dishonorable or they won't accept the payoff. You may be double crossed. The payoffs, while deferring the pressure for a time, may cause bigger problems later on for obvious reasons because of the illegality involved ... It is not a matter of being a Sunday School advocate of morality, although that is important, but it is a matter of having hard, practical sense. Once you go down the road of bribery, you are likely to be in serious trouble. It is bad economics as well as bad morality. ${ }^{19}$

A Senate Report stated as follows: 'There is a broad consensus that the payment of bribes to influence business decisions corrodes the freeenterprise system. Bribery short-circuits the marketplace. Where bribes are paid, business is directed not to the most efficient producer, but to the most corrupt. This misallocates resources and reduces economic efficiency.' ${ }^{20}$

The view was also expressed that prohibiting payments to foreign government officials could give U.S. companies a comparative advantage and actually help companies resist foreign payment demands. During a Senate hearing, the Chairman of the Board of Gulf Corporation, stated:

You can help us and many other multinational companies which are confronted with this problem by enacting legislation which would outlaw any foreign contributions by an American company. Such a statute on our books would make it easier to resist the very intense pressures which are placed upon us from time to time. ${ }^{21}$ 
This observation was repeated often by congressional leaders who favored a direct payment prohibition. Senator Proxmire stated during a Senate hearing:

I just conclude by pointing out how widespread the desire in the business community is for this kind of legislation. [The Chairman of Gulf Corporation] ... indicated how helpful this kind of a law would have been for him. He said, such a statute on our books would make it easier to resist the very intense pressures which are placed on corporate officials from time to time. If they could cite our law which says we just may not do it, they would be in a better position to resist these pressures and refuse these requests. ${ }^{22}$

The perception that a direct payment prohibition could actually help U.S. companies resist foreign payment demands was also shared by others who testified during congressional hearings. For instance, an SEC Commissioner stated:

I think that, if you could devise a workable mechanism for making these payments illegal, you could then give the American executive a degree of bargaining power. He could say: No. I would like to do it, but I can't because it is illegal,' so that I would be disposed to think that might be a good idea. ${ }^{23}$

Notably, a Senate Report stated as follows: 'A strong anti-bribery law would help U.S. multinational companies resist corrupt demands, and would enhance the reputation of U.S. business abroad.' ${ }^{24}$

A final factor evidenced in the legislative record motivating Congress to act was a recognition that U.S. companies were part of a world-wide problem, and that if the U.S. took a leadership position other countries would soon follow in enacting laws governing business conduct with foreign government officials in foreign markets.

For instance, Senator Proxmire stated:

... It's to the great interest of every country that the people who sell to them don't bribe. Now if we have a reputation of being the one country that enforces the law and everything that we sell is sold on the basis of merit and competition and not on the basis of bribery, it seems to me that's an enormous advantage that shouldn't be overlooked. I would think unilateral action wouldn't isolate us. It would give us a great advantage and other countries would per force be constrained to follow. ${ }^{25}$

\section{Deficiencies in Existing Law}

Upon discovery of the foreign corporate payments problem, Congress's first task was to determine if the payments were adequately captured by 
existing law. While certain existing laws did indirectly deal with various aspects of the problem, you will learn in this section that the prevailing view was that existing laws were deficient and that a new and direct legislative remedy was needed.

In 1975 the House held a series of hearings largely focused on whether the discovered payments were already a violation of U.S. law. In opening the hearing, Representative Nix stated:

Such payments to foreign officials are not a violation of American law at present, although they are very often a violation of foreign law. However, it is a requirement of the United States Code that American corporations make full disclosure of their assets and liabilities to the Securities and Exchange Commission, the Civil Aeronautics Board, and the Internal Revenue Service. It is also true that if the purpose of the payments was anticompetitive in intent, the Antitrust Division of the Department of Justice would have a basis to begin legal proceedings ... We may need improvements in our law. There is always room for improvement. ... Our hearing will continue until we can answer positively whether our present legal system can meet the challenge of foreign slush funds maintained by the foreign operations of American-based companies. Of course, that does not confine the operations of this subcommittee; it seeks to explore, to examine and to suggest legislation that will meet the needs of the problem that we face. ${ }^{26}$

Likewise, in opening a 1976 hearing, Senator Proxmire stated:

By now, close to 100 publicly-held corporations have made disclosures to the [SEC] under the SEC's so-called voluntary program, of literally hundreds of millions of dollars paid over the years as bribes to foreign officials and political parties. This bloodletting, unfortunately, is continuing. It is the disgrace of our free enterprise system. In turn, the practice of bribing foreign officials has corrupted those paying the bribes, and has corrupted the free market system, under which the most efficient producers with the best products are supposed to prevail. There was a time when defenders of corporate bribery argued that you had to make under-the-table payments in order to compete in certain parts of the world. By now, I think, no responsible person would make that claim. ... Yet, I fear, even though the issue is settled in theory, that many companies will continue paying bribes if they can get away with it, because the potential rewards are so great and the risks are minimal. Nobody has gone to jail. Only three corporations have fired their chief executive officers. At most, there has been some unfortunate publicity. Even Lockheed is reporting increased profits. And so we come to the need for a remedy. In my view, U.S. corporations should be prohibited from paying bribes anywhere in the world. They are already prohibited from paying bribes at home. ${ }^{27}$

During the hearing, Senator Proxmire further stated: 
What we are concerned about is the kind of payment that Lockheed, for example, engaged in and admits where a payment is made to a foreign official indirectly for the purpose of selling what that corporation has to sell to that country. It is a bribe. Now that kind of payment is not outlawed at the present time in our law and while it is outlawed in many foreign countries ... it's very hard for those countries to prosecute because they don't have the facts. We may have the facts but we don't prosecute because it's not against the law. We are trying to bridge that situation and provide a provision in the law that would make this illegal so we have the basis for action. ${ }^{28}$

The primary focus of Congress's investigation was whether the existing securities laws, tax laws and/or antitrust laws adequately addressed the foreign corporate payments problem.

As to the securities laws, early in Congress's investigation of the problem, the SEC Chairman highlighted the potential deficiencies of the securities laws as a comprehensive solution to the problem. In a speech included in the legislative record he stated:

The significance of this illegality and immorality is far from clear in all instances. Are we saying that every improper expenditure must be disclosed, as such, giving details, because it is improper regardless of other considerations? We are not saying that. At least we have not said it so far, and I, at least, do not propose that we should ever say it. ... We are not concerned with corporate morality as such - just disclosure of material facts ... . We do not regard ourselves as having a mandate to enforce, even indirectly, through compulsory disclosure, all of the world's laws and all of its perceptions of morality and right conduct. Some forbearance not only seems implicit in our governing statutes, but also may be essential to enable us to continue to do a competent job of investor protection .... As you can see, if we require disclosure of all violations of laws against bribery or political contributions on the ground that illegal payments are material per se, we may be hard pressed to explain that other illegal corporate acts are not equally material for the same reason .... If improper foreign expenditures are not to be regarded as material simply because they are improper, without more, what principles govern the separation of those that are material and those that are not? Is it the method by which payments are made, the size of the payments, the purpose for which they are made, or the hazards to the business for exposure of the payments? It is, I believe, all of these, in different proportions in different situations. ${ }^{29}$

An SEC Commissioner further indicated that 'the mere fact that a foreign payment has been made, particularly in a relatively small amount, is not necessarily a material fact to investors,' and 'there is a significant question as to the extent to which information about foreign payments, even if illegal under foreign law or our law, or regarded as being 
improper, is material to an investor in appraising investment in a very large corporation.' 30

The SEC Commissioner further stated:

While it is true that we have and have exercised authority to deal with the problem of companies that have maintained false books and records, there is no explicit requirement under the Federal securities laws dealing with that problem or, more to the point, requiring that corporations establish and maintain adequate systems of internal controls. ${ }^{31}$

Regarding the key concept of materiality under the securities laws, the SEC Commissioner stated:

The problem is that the payment has to be disclosed only if it is material for purposes of our disclosure requirements. A company that is doing business abroad makes payments of numerous amounts for numerous purposes. They don't have to itemize each one of them in their disclosure documents with us, so that the mere fact that they made a payment would not necessarily have to be disclosed under our existing requirements. ${ }^{32}$

Senator Proxmire, in particular, was unconvinced that the existing securities law requirement of material disclosures, applicable only to publicly-held companies, was an effective remedy to the problem. Noting the SEC's position 'that disclosure of the identity of a recipient of a bribe is probably unnecessary because it may be of little significance to the investor,' Senator Proxmire stated:

That is precisely the problem with tying it to materiality. It may indeed be immaterial to the investor. There is nonetheless a very good justification for a public policy requiring disclosure of the recipient of a bribe. The purpose is simply to inhibit the bribe in the first place. But by tying it to materiality in every case it becomes necessary to disclose a different defense which is really not material to our purpose here. ${ }^{33}$

As to whether existing tax laws adequately captured the discovered payments, an Internal Revenue Service official stated during a House hearing:

In plain language, the Internal Revenue Code prohibits the allowance of any deduction for moneys paid to a foreign official if a similar payment would have been unlawful under the Federal statutes of the United States, whether or not the payment is lawful under the laws of the particular country employing the foreign official who receives the payment or the benefit of the payment. ${ }^{34}$ 
Thus, under the tax laws, the improper conduct was not in making the payment, but rather deducting the payment for tax purposes.

As to whether existing antitrust laws adequately captured the discovered payments, during a House hearing a DOJ antitrust official set forth various different 'hypothetical situations involving payments to foreign officials which might raise problems' under existing antitrust laws and stated:

The kind of bribe, about which we have been reading a good deal recently, would most certainly not be, in itself, an antitrust violation. The reason is that such bribes are unlikely to have any direct and identifiable effect on U.S. foreign commerce. The bribe is not intended to harm a U.S. competitor's export opportunities. In sum, neither payment nor the withholding of payment can be directly related to the flow of imports into or exports from U.S. markets. ${ }^{35}$

The official concluded his testimony as follows:

I am not sure I feel fully qualified to comment on the whole question of whether we ought to have a specific foreign bribery law. ... If the Congress feels - and I hear you very clearly as saying that this is an important problem we have got to do something about, then I think you had better look to a criminal law dealing specifically with the international bribery situation or expanding the scope of it and not look to the antitrust laws as the way of dealing with it in a general way. ${ }^{36}$

As to whether a new legislative remedy was needed to capture the discovered foreign payments, the following statement by the Chairman of the Board of Lockheed best sums up the then-existing landscape.

So it is true that we knew about the practice of payments on some occasions to foreign officials. But so did everyone else who was at all knowledgeable about foreign sales. There were no U.S. rules or laws which banned the practice or made it illegal ... . No effort was made to condone such payments except to say ... that it was thought that it appeared to be necessary to make such payments in order to compete successfully in many parts of the world. ... If Congress passes laws dealing with commissions and direct or indirect payments to foreign officials in other countries, Lockheed, of course, will fully comply with them. ${ }^{37}$

\section{Divergent Views within the Government as to a Solution and the Difficult and Complex Issues Encountered}

Seeking new legislative remedies to the foreign corporate payments problem was far from a consensus view of the government, and the 
payments discovered were not the simple and safe issue they appeared to be at first blush. As Representative Eckhardt stated, 'despite the clear consensus at our hearings that foreign bribery is a reprehensible activity and effective remedial legislation is required, there were some differences in approach to this problem. ${ }^{38}$

Numerous government agencies participated in congressional hearings and all expressed universal condemnation of the discovered payments. However, beyond such unsurprising statements, you will learn in this section of the deep divisions within the government as to the solution. Moreover, certain segments of the government were viewed by congressional leaders as being participants in, or at least enablers of, the very problem Congress was seeking to address.

For instance, while the State Department condemned the payments, it opposed unilateral U.S. legislation governing the conduct of U.S. citizens abroad in their relations with foreign government officials. During a House hearing, a State Department official stated:

What, then, should be done? ... We need to move carefully. Some have suggested that we should enact legislation making it a criminal act for U.S. companies to engage abroad in what we regard as improper activities here at home, such as corporate political contributions. Although investors operating in foreign lands would be wise to avoid even the appearance of impropriety in those countries, we believe it would not be advisable for the United States to try to legislate the limits of permissible conduct by our firms abroad. It would be not only presumptuous but counterproductive to seek to impose our specific standards in countries with differing histories and cultures. Moreover, enforcement of such legislation - and I think this is the most important point - would involve surveillance of the activities of foreign officials as well as U.S. businessmen and would be widely resented abroad. Extraterritorial application of U.S. law - which is what such legislation would entail - has often been viewed by other governments as a sign of U.S. arrogance or even as interference in their internal affairs. U.S. penal laws are normally based on territorial jurisdiction and, with rare exceptions, we believe that is sound policy. [...] Corruption of friendly foreign governments can undermine the most important objectives of our foreign policy. But experience shows the United States cannot police the internal affairs of foreign states. In the final analysis the only solution to corruption lies in the societies concerned. ${ }^{39}$

Congressional leaders were troubled that the State Department was perhaps a participant in, or at least enabler of, the very problem Congress was seeking to address. The following exchange between Senator Jesse Helms and Lockheed's Chairman during a Senate hearing highlights this issue: 
Helms: 'Do you feel that these bribes or whatever name may be applied to them came as any surprise to the Government of the United States, specifically of the State Department?'

[...]

Chairman: 'I don't believe they came as any surprise to the State Department or to other branches of the U.S. Government.' 40

Senator Helms directed the following statement to State Department officials during a hearing:

I certainly don't want to even have the appearance of badgering you, and I don't want to belabor the point, but I am somewhat mystified in the light of all the reports that have come to me, sir, that apparently at the State Department during all of these years when these things were alleged to have occurred, that there was a complete 'hear no evil and see no evil.' Now, just tell me this one more time. Nobody at the State Department ever dreamed anything of this sort was going on at any time? ${ }^{41}$

On the Senate floor, Senator Church stated as follows regarding the State Department's perceived role in the problem:

In all the months that we have investigated the practices of multi-milliondollar bribes and payoffs all over the world, we have yet to find any evidence of State Department concern or State Department initiative taken at any time to deal with the problem. When these bribes were finally exposed, they delayed for months even taking token action. So I really do not think the State Department wants any legislation in this field. I believe their attitude fairly could be characterized as one of indifference or perhaps benign neglect. ${ }^{42}$

Like the State Department, the Defense Department was also viewed by congressional leaders as being a participant in, or at least enablers of, the very problem Congress was seeking to address. Certain of the discovered foreign corporate payments involved defense contractor use of foreign agents in connection with foreign government business and among the series of House hearings in 1975 was one focused on the role of agents in foreign military sales. In opening the hearing, Representative Nix stated:

The specific issue we are considering today is the part played in military sales contracts by foreign sales agents and the fees paid to them. [...] The Defense Department has at its disposal immense amounts of information on this very issue. No interest has been shown by the Department in this issue, in that its mission appears to be the promotion of arms sales. ${ }^{43}$ 
As to the Defense Department's role in the problem, Representative Solarz stated as follows: 'There were some recent revelations to the effect that the Defense Department had advised American arms people doing business to the effect that payoffs were a traditional way in that part of the world of facilitating the kind of transactions which they were interested in.' 44

Likewise, Senator Proxmire noted during a Senate hearing:

One of the most disturbing aspects of this is the role the Defense Department has played, especially with respect to defense contractors who sold abroad. We have a document which indicates that at one point a top official in the Defense Department had counseled defense contractors on paying bribes and urged them to do so under circumstances where it was necessary. ${ }^{45}$

The clear divisions within the government concerning the foreign corporate payments problem, as well as a lack of concern by certain segments of the government, were summarized by Senator Church as follows:

Our Government has initiated no real concern with this problem. Rather, aside from some statements of a cosmetic nature, it prefers to stick its head in the sand and hear no evil, see no evil, and pretend there is no problem. But there is a problem, a problem of cancerous dimensions which is eating away at the vitals of democratic society. So there is a need for action, and action now. ${ }^{46}$

Despite Senator Church's call for action, many difficult and complex issues emerged as Congress considered solutions, and the payments discovered were not the simple and safe issue they appeared to be at first blush. The following exchange between Senator Proxmire and the Secretary of Commerce best captures this dynamic. Senator Proxmire stated during a Senate hearing:

For more than a year now the [SEC] and the [Church Committee] have been generating reams of evidence on foreign bribery. [...] Yet it seems as if some, who rhetorically condemn bribery as roundly as the rest, want Congress to delay a remedy until the entire Fortune 500 have been investigated. I recall the story of an agency in the bureaucracy that was short on bureaucrats. They hired a talking parrot. [...] They taught him to say only one phrase: 'Very complex, very complex.' Sometimes I get the feeling that the parrot, that very complex parrot, is in charge of the Federal Government's groping, grasping policy on bribery. Certainly, there are subtleties and complexities in the foreign bribery issue, but we should be able to agree after more than a year of investigation the time has come to provide a remedy for an act as simple and outrageous as bribery. ${ }^{47}$ 
In response, the Secretary of Commerce stated:

Even a parrot must occasionally be right ... What I am saying ... is that in the bribery area we are moving into uncharted national and international waters in which legislative remedies may be capable of achieving only part of the objectives we seek. As part of the process of considering specific legislative remedies, we should be certain that we have a clear understanding of the scope and magnitude of the problems to be addressed, a thorough assessment of the costs and benefits of the legislative remedies being advanced, and a reasonably precise plan for moving from where we are now to where we wish to be. ${ }^{48}$

As to the foreign business conditions giving rise to many of the discovered payments, an SEC Commissioner stated during a House hearing:

These questionable payments by American corporations in foreign countries present a number of difficult problems for us, and for you in your deliberations ... . For one thing, the exact purpose of such payments is often difficult to determine. It is normal and understandable that American corporations seeking to do business abroad will employ or retain sales agents, business consultants and others who are on the scene and familiar with local ways of doing business. Payments made to such intermediaries are often entirely proper, but may not always be so. Once the money is in the hands of a foreign agent, it may be difficult to determine exactly what he does with it. Of course, suspicions are always raised where large sums are paid for unexplained services and it is hard to determine exactly what the company is receiving for its money. We are told that in many countries it is almost customary to distribute various gratuities to persons in strategic positions in order to obtain favorable treatment. Indeed, such practices are not wholly unknown in the United States. These payments may or may not violate the laws of the country involved, and in countries having entirely different legal systems from the United States, local law on the subject may be quite obscure. But, even where a payment does not violate the law of the country involved, it is to be expected that foreign officials and governments would be sensitive to publicity about such payments and, therefore, such publicity may jeopardize the position of a company in foreign countries. Thus, while I am sure we can all agree that American companies should not, as a matter of principle, make payments to officials of foreign governments in return for favored treatment, it is often difficult to determine whether or not this has occurred. Moreover, we are not insensitive either to the difficulties American companies experience in doing business abroad, or to the fact that our lawsuits might create an impression in some minds of United States interference in the affairs of foreign countries. ${ }^{49}$

Highlighting many of these same issues, a representative of the New York City Bar who testified at a House hearing stated: 
Without in any way excusing the failures of U.S. business that have been exposed over the last 2 years - and I don't think they can be excused - the problem goes beyond those failures. It is not really addressing the whole problem to say that we need only look at the failure of U.S. business and not look at the context in which those failures occurred. We know from the evidence that has been exposed so far that in many cases the bribes were solicited, not volunteered. We know that there were cases of extortion. [...] We know, beyond that, from some of the filings with the SEC and from other sources, that it wasn't just U.S. business that was involved, and we certainly have reason to say that perhaps these practices in other countries were tolerated there. ${ }^{50}$

Yet just because foreign business conditions presented difficult issues for U.S. companies, all were not persuaded that this made the payments any less problematic. For instance, Senator Church stated during a Senate hearing:

While such methods may be common practice abroad, I am skeptical of the argument that it is perfectly all right because everyone does it. I know of no country where bribes and kickbacks are either legal or publicly accepted. And the fact that the corporations, by their own admission, go to such lengths to disguise these practices, through the use of double bookkeeping, numbered Swiss bank accounts, and a system of code names that would do credit to the CIA, puts the lie to the argument that it is accepted practice. ${ }^{51}$

In addition to the issues Congress encountered regarding foreign business conditions, there was also concern that U.S. companies might be placed in a competitive disadvantage if Congress passed a unilateral law governing business interaction with foreign government officials. Despite such concerns, a certain degree of competitive disadvantage was accepted by Congress. For instance, Representative Moss stated during a House hearing:

To think that no loss of business would occur in every instance would be unrealistic. Can we allow this to occur? Yes, if that is the small price we must pay to return morality to corporate practice. Yes, if that is the small price we pay to show that U.S. firms compete in terms of price, quality, and service and not in terms of the size of a bribe. Real competition works. The vast majority of American companies have operated successfully in foreign countries without the need to resort to bribery. ${ }^{52}$

Likewise, the Treasury Secretary stated during the same hearing: 'To the very, very small extent a particular company may lose a particular contract because it refuses to engage in this practice, I would be willing 
to say, all right, we will be at a slight competitive disadvantage and we will all sleep the better for it. ${ }^{53}$

Foreign business conditions and competitive disadvantage issues aside, Congress also encountered the basic issue of defining bribery. The Treasury Secretary stated during a Senate Hearing:

You know that trying to define exactly what bribery is is a real problem. You and I would have no trouble saying what a bribe is and what isn't. However, having said that, it's very difficult to put it down on paper in statutory language that would not be damaging to some legitimate things that happen on the periphery, such as payments of commissions. It's almost like the Justice who said that he can't define pornography, but he knows what it is when he sees it. In certain instances, we have a gray area when it comes to this bribery question. Outright payment to secure a particular contract to an official of a foreign government, fine, we have no trouble with defining that as a bribe. Payment of commissions to agent, which is an accepted practice throughout the world, is another matter. ${ }^{54}$

\section{Legislative Proposals Leading to Enactment of the FCPA}

Notwithstanding the many difficult and complex issues encountered, Congress proceeded to seek legislative remedies to the foreign corporate payments problem. Between 1975 and 1977, approximately twenty bills were introduced in the Senate or the House to address the foreign corporate payments problem. Although Congress sought to address the problem from a variety of angles (such as through amendments to the Internal Revenue Code, termination of Overseas Private Investment Corporation insurance and disclosure of foreign agent fees), this section details the two main competing legislative responses that emerged: a disclosure approach as to a broad category of payments and a criminalization approach as to a narrow category of payments.

As described in more detail below in a general chronology, the Ford administration favored a disclosure approach as to a broad category of payments. However, key congressional leaders, as well as the Carter administration, which took office in early 1977, favored a criminalization approach as a narrow category of payments. Despite significant minority concern, the FCPA adopted a criminalization approach as it was viewed as more effective in deterring improper payments and less burdensome on business.

In early 1976, with legislative activity intensifying and after being viewed as exhibiting indifference to Congress's nearly year-long investigation of the problem, President Gerald Ford issued a memorandum to 
various federal agencies establishing a 'Task Force on Questionable Corporate Payments Abroad' (the 'Task Force'). The memorandum stated:

This is to advise you of my decision to appoint you to a Cabinet-level Task Force which I am establishing to examine the policy aspects of recent disclosures of questionable payments to foreign agents and officials by U.S. companies in conjunction with their overseas business operations. [...] Although the Federal Government is currently taking a number of international and domestic steps in an attempt to deal with this problem, I believe that a coordinated program to review these efforts and to explore additional avenues should be undertaken in the interest of ethical conduct in the international marketplace and the continued vitality of our free enterprise system. The full dimensions of this problem are not yet known but it is clear that a substantial number of U.S. corporations have been involved in questionable payments to foreign officials, political organizations or business agents. The possibility exists that more can be done by our government. There would also appear to be some interest in guidance as to what standards should be applied to the foreign sales activities of the overwhelming majority of American businessmen who are deeply concerned about the propriety of their business operations. The Task Force should explore all aspects of this problem and seek to obtain the views of the broadest base of interested groups and individuals. While the problems are complex and do not lend themselves to simple solutions, I am confident that your labors will contribute to a better international and domestic climate in which American business continues to play a vital and respected role. ${ }^{55}$

In a 1976 letter to Senator Proxmire, the Secretary of Commerce set forth the views of the Task Force on 'proposed legislation concerning questionable corporate payments abroad.' The letter stated:

There are two principal competing general legislative approaches - a disclosure approach or a criminal approach. While it is possible to design legislation [...] which requires disclosure of foreign payments and makes certain payments criminal under U.S. law, the Task Force has unanimously rejected this approach. The disclosure-plus-criminalization scheme would, by its very ambition, be ineffective. The existence of criminal penalties for certain questionable payments would deter their disclosure and thus the positive value of the disclosure provisions would be reduced. In our opinion the two approaches cannot be compatibly joined. The Task Force has given considerable scrutiny to the option of 'criminalizing' under U.S. law improper payments made to foreign officials by U.S. corporations. Such legislation would represent the most forceful possible rhetorical assertion by the President and the Congress of our abhorrence of such conduct. It would place business executives on clear and unequivocal notice that such practices should stop. It would make it easier for some corporations to resist pressures to make questionable payments. The Task Force has concluded, however, that the 
criminalization approach would represent little more than a policy assertion, for the enforcement of such a law would be very difficult it not impossible. Successful prosecution of offenses would typically depend upon witnesses and information beyond the reach of U.S. judicial process. Other nations, rather than assisting in such prosecutions, might resist cooperation because of considerations of national preference or sovereignty. Other nations might be especially offended if we sought to apply criminal sanctions to foreignincorporated and/or foreign-managed subsidiaries of American corporations. The Task Force has concluded that unless reasonably enforceable criminal sanctions were devised, the criminal approach would represent poor public policy. The Task Force has similarly analyzed the desirability of new legislation to require more systematic and informative reporting and disclosure than is provided by current law. The Task Force recognized that additional disclosure requirements could expand the paperwork burden of American businesses ... and that they might, in some cases, result in foreign relations problems - to the extent the systematic reporting and disclosure failed to deter questionable payments and their publication proved embarrassing to friendly governments. At the same time the Task Force perceived several very positive attributes of systematic disclosure. First, it deemed such disclosure necessary to supplement current SEC disclosure, which as noted already covers only issuers of securities making 'material' payments, and does not normally include the name of the payee. Such disclosure would provide protection for U.S. businessmen from extortion and other improper pressures, since would-be extorters would have to be willing to risk the pressures which would result from disclosure of their actions to the U.S. public and to their own governments. It would avoid the difficult problems of defining and proving 'bribery.' It would offer a means to give public reassurance of the essential accountability of multinational corporations ... . The President has decided to recommend that the Congress enact legislation providing for full and systematic reporting and disclosure of payments made by American businesses with the intent of influencing, directly or indirectly, the conduct of foreign governmental officials. At the same time, the President has decided to oppose, as essentially unenforceable, legislation which would seek broad criminal proscription of improper payments made in foreign jurisdictions. ${ }^{56}$

Shortly thereafter, President Ford announced 'three new initiatives' based on the findings of the Task Force. In the announcement, President Ford stated: 'As a deterrent to bribery by American-controlled industries, I am directing the task force to prepare legislation that would require corporate disclosure of all payments made with the intention of influencing foreign government officials. Failure to comply with the new disclosure laws would lead to civil and criminal penalties.' ${ }^{57}$

President Ford also urged enactment of the proposed legislation and stated: 
I am transmitting to the Congress my specific proposal for a Foreign Payments Disclosure Act. This proposal will contribute significantly to the deterrence of future improper practices and to the restoration of confidence in American business standards. This legislation represents a measured but effective approach to the problem of questionable corporate payments abroad: It will help deter improper payments in international commerce by American corporations and their officers. It will help reverse the trend toward allegations or assumptions of guilt-by-association impugning the integrity of American business generally. It will help deter would-be foreign extorters from seeking improper payments from American businessmen. It will allow the United States to set a forceful example to our trading partners and competitors regarding the imperative need to end improper business practices. It does not attempt to apply directly United States criminal statutes in foreign states and thus does not promise more than can be enforced. Finally, it will help restore the confidence of the American people and our trading partners in the ethical standards of the American business community. ${ }^{58}$

Bills based on the Task Force's recommendations were soon introduced and at Congressional hearings that ensued, a Department of Commerce official stated as follows in advocating the Ford administration position:

The existence of the criminal prosecution would be of some value to an American businessman in resisting improper requests for payments abroad. I don't believe, however, that it would have as much value as the disclosure requirements, for the following reasons. A would-be foreign extorter who asks for $\$ 50,000$ to do something of importance to the American company, on the one hand would be told, 'I can't give you that money because if I do I might have to go to jail,' and the extorter says, 'That is your problem, bud, but there is no way, your law can reach me.' If you have a disclosure provision and the American businessman says, 'If I give you that money, I am going to have to report the payment to the Department of Commerce, possibly to the SEC, and it will therefore be in the public record, and your name will be in the public record.' If we are right that every other country in the world, virtually every other country, has laws against public bribery and extortion, then it is our guess that the extorter will be substantially deterred. We believe that a combination of sunlight and encouragement of other nations to enforce their own laws represents a much more effective way to end corrupt payments than does direct, unilateral criminalization by this country of actions taking place in foreign jurisdictions. We urge the Congress not to substitute tokenism for real action to deal with the questionable payments problem. The danger in such tokenism is that it will create complacency. Congress will wash its hands of an important problem without having taken meaningful, enforceable action. $^{59}$

However, many were not convinced that the Task Force-inspired disclosure legislation was an adequate response to the problem. In a 
passionate statement which speaks to the political context of Congress's deliberations, a witness stated during a 1976 House hearing:

The principal policy issue raised ... of course, is whether [the bill] should prohibit the bribery of foreign officials at all. The Ford administration ... prefers to rely solely upon the offending corporation notifying the Department of Commerce of its misdeed, with the Department not making that fact known until as much as a year later, and then only if our national interest would not be adversely affected. What a pitifully pallid response to a major moral crisis. Have we learned nothing from the attempted coverup of Watergate? Have we no shame, no decent respect for the opinions of mankind? How could this country continue to preach abroad the virtues of the free competitive market system and continue to call for economic justice and political integrity, how could we hope to avoid unreasonable restrictions and attacks on American corporations abroad, if we are unwilling to specially and directly prohibit and penalize this wasteful, corrosive, shabby practice? Do we really wish to align ourselves around the world with the cynical and the corrupt, with those who profit from bribery or wink at it as customary and unavoidable, or should we not instead align ourselves with those business and government officials who have stoutly resisted all pressures and temptations, and who would be vastly relieved today if a U.S. criminal statute said loudly and clearly that all U.S.-based enterprises continuing to engage in such practices did so at their own peril. ${ }^{60}$

The Task Force-inspired disclosure legislation did not gain traction in Congress, but a bill introduced by Senator Proxmire that sought to directly criminalize payments to foreign officials did. The bill was soon reported to the Senate and the Senate Report stated as follows:

The Committee considered two approaches for curbing the kind of bribery payments to foreign officials ... One approach would be to require that these bribes be publicly disclosed. The other approach would be to prohibit them by law with criminal penalties for those who violate the law. The disclosure approach was ... recommended by the [Task Force]. The Task Force report to the Committee argued that disclosure would constitute an effective deterrent whereas an outright criminal prohibition would be difficult to enforce. The Committee carefully weighed these arguments and decided that a direct criminal prohibition is the better approach. As the Task Force itself pointed out, a direct criminal prohibition of foreign bribes 'would represent the most forceful possible rhetorical assertion by the President and the Congress to our abhorrence of such conduct. It would place business executives on clear and unequivocal notice that such practices should stop. It would make it easier for some corporations to resist pressures to make questionable payments.' On the other hand, merely requiring the disclosure of bribes would leave ambiguous whether such payments might be acceptable. Indeed, it would imply that bribery can be condoned as long as it is disclosed. The Committee considered whether a criminal prohibition might be more difficult to enforce than a 
disclosure requirement. The Committee concluded that an outright prohibition would be at least as feasible to enforce as any meaningful disclosure requirement. Under the disclosure approach ..., all payments made to foreign officials for the purpose of 'obtaining or maintaining business with or influencing the conduct of a foreign government' would have to be disclosed. Clearly, in order to enforce such a disclosure requirement and apply sanctions for failure to file reports, it would be necessary to prove that an undisclosed payment was actually made, and that it was made with an improper purpose. Thus, the same evidence necessary to prove a violation of a direct prohibition would have to be marshaled in order to enforce a disclosure statute. Beyond that, there would be the additional burden of proving that an issuer willfully failed to file a report describing the bribe. Accordingly, the Committee concluded that a disclosure approach has at least the same enforcement problems inherent in the direct prohibition approach and none of its advantages. The bill, as reported, therefore, provides a direct criminal prohibition. ${ }^{61}$

The Senate unanimously passed the bill and it was referred to the House. However, House efforts to address the foreign corporate payments problem paused for the 1976 elections in which the Democratic candidate Jimmy Carter defeated Republican President Ford. During the campaign, Carter 'derided the [Ford] administration's ... "proposal to allow corporations to engage in bribery so long as they report such illegal transactions to the Department of Commerce." 62 As Representative Michael Harrington stated after Carter took office, 'we now have an administration whose prime foreign policy concern to date has been to restore morality and ethical principles to all of our international relations. ${ }^{63}$

When Congress opened after the 1976 elections, legislative efforts to address the foreign corporate payments problem soon renewed, and focused on bills with criminal payment provisions. With President Ford out of office, the Task Force-inspired disclosure legislation fell by the wayside. In early 1977 Senator Proxmire introduced a bill similar to the one previously passed by the Senate and stated as follows.

Last year this bill passed the Senate by a unanimous vote [...] . Let's not kid ourselves. This bill is not home free. It was stopped last year in the House by the opposition of those objecting to the provisions of the bill. It will take strong support from the administration and those of us in Congress who believe in it to get the bill passed. ${ }^{64}$

\section{The Senate Report stated:}

The committee ... concluded that the criminalization approach was preferred over a disclosure approach. Direct criminalization entails no reporting burden on corporations and less of an enforcement burden on the Government. The 
criminalization of foreign corporate bribery will to a significant extent act as a self-enforcing, preventative mechanism. ${ }^{65}$

In the House, Representative Eckhardt introduced a bill, which in compromise with the Senate bill, ultimately become the FCPA. The House Report stated:

The committee considered two possible approaches for curbing the type of bribery payments defined [in the bill]. One approach is to require that these payments be publicly disclosed and criminal penalties imposed for failure to disclose. The other approach, which the committee adopted [...] is to outlaw the payoffs with criminal sanctions.

The [House] received extensive testimony on both approaches ... There emerged a clear consensus that foreign bribery is a reprehensible activity and that action must be taken to proscribe it. After carefully considering all the testimony adduced, the committee concluded that it should be outlawed rather than legalized through disclosure. The committee believes the criminalization approach to be the most effective deterrent, the least burdensome on business, and no more difficult to enforce than disclosure.

The committee determined that disclosure can never be an effective deterrent because the anticipated benefit of making a bribe, such as winning a multimillion dollar contract, generally exceeds the adverse effect, if any, of disclosing one year later a lump sum figure without names, amounts or even countries. Criminalization, on the other hand, has proven an effective deterrent.

\section{[...]}

The committee also found that criminalization is no more difficult to enforce than disclosure. Both approaches involve proving beyond a reasonable doubt the same factual and legal elements. Most importantly, though, criminalization is far less burdensome on business. Most disclosure proposals would require U.S. corporations doing business abroad to report all foreign payments including perfectly legal payments such as for promotional purposes and for sales commissions. A disclosure scheme, unlike outright prohibition, would require U.S. corporations to contend not only with an additional bureaucratic overlay but also with massive paperwork requirements. ${ }^{66}$

As to a criminal prohibition of a narrow category of payments being less burdensome on business than a broader disclosure provision, Representative Eckhardt stated:

Disclosure legislation must embrace a wide range of activities, many of which appear perfectly legal and even ethical. And of course, if they must all be disclosed, along with that which is illegal, one may assume that the acts most readily disclosed will be those which are innocent acts. [...] A significant 
difference between the two approaches, often overlooked, is that criminalization is far less burdensome on business. Disclosure would require U.S. corporations doing business abroad to report all foreign payments including legal promotional payments and legitimate commissions to sales agents. ${ }^{67}$

In late 1977, all that remained was for Congressional conferees to iron out certain differences between a House bill and a Senate bill.

In short, the prevailing view was that the criminalization approach represented the best legislative response to the foreign corporate payments problem. In late 1977, after more than two years of investigation and consideration of the foreign corporate payments problem, and despite divergent views as to the problem and the difficult and complex issues presented, Congress completed its pioneering journey and passed the first law in the world governing domestic business conduct with foreign government officials in foreign markets. Speaking on the House floor, Representative Eckhardt summed up the journey and stated that the FCPA was 'one of the more important pieces of legislation to be considered by the Congress this year.' 68

In December 1977, the FCPA became law as an amendment to the Securities Exchange Act of 1934. President Carter's signing statement stated:

I am pleased to sign into law [...] the Foreign Corrupt Practices Act of 1977 and the Domestic and Foreign Investment Improved Disclosure Act of 1977. During my campaign for the Presidency, I repeatedly stressed the need for tough legislation to prohibit corporate bribery. [This bill] provides that necessary sanction. I share Congress' belief that bribery is ethically repugnant and competitively unnecessary. Corrupt practices between corporations and public officials overseas undermine the integrity and stability of governments and harm our relations with other countries. Recent revelations of widespread overseas bribery have eroded public confidence in our basic institutions. This law makes corrupt payments to foreign officials illegal under United States law. It requires publicly-held corporations to keep accurate books and records and establish accounting controls to prevent the use of 'off-the-books' devices, which have been used to disguise corporate bribes in the past. [...] These efforts, however, can only be fully successful in combating bribery and extortion if other countries and business itself take comparable action. Therefore, I hope progress will continue in the United Nations toward the negotiation of a treaty on illicit payments. ${ }^{69}$

\section{The FCPA as a Limited Statute}

Even though the FCPA was a pioneering statute, Congress intended for it to be a limited statute. In this section, you will learn that Congress was 
aware of a wide range of foreign corporate payments to a variety of recipients for a variety of reasons. However, Congress accepted in passing the FCPA to capture only a narrow category of such payments.

Among other things, you will learn in this section that Congress limited the FCPA's payment provisions to a narrow category of foreign recipients and further narrowed the range of actionable payments to those involving foreign government procurement or influencing foreign government legislation or regulations. In addition, Congress chose not to capture so-called facilitating payments given the difficult and complex business conditions encountered in many foreign markets.

During Congress's multi-year investigation of the foreign corporate payments problem, it learned of a wide range of foreign corporate payments to a variety of recipients for a variety of reasons. The SEC Report, which Congress placed great reliance on during its deliberation and consideration of the problem, contained an entire section titled 'Recipients of the Payments' and stated:

The nature of the recipient often has been an important factor in determining that a corporate payment was a disclosable event. Various classes of recipients have presented these considerations, including but not limited to government officials, commission agents and consultants of the paying company, and recipients of commercial bribery.

Government Officials: [...] The Commission has observed payments to government officials for four principal purposes. First, corporate payments have been made in an effort to procure special and unjustified favors or advantages in the enactment or administration of the tax or other laws of the country in question. ... Second, corporate payments may be made with the intent to assist the company in obtaining or retaining government contracts. It may be possible to distinguish payments intended to secure the favorable exercise of judgment or discretion on behalf of the governmental body from situations where the official, under applicable laws, regulations or customs, appears to have been permitted to act for suppliers in connection with government contracts and to be paid for such services. ... A third purpose for payments is to persuade low-level governmental officials to perform functions or services which they are obliged to perform as part of their governmental responsibilities, but which they may refuse or delay unless compensated. ... Another type of payment is the political contribution. Where these contributions are illegal under local law, they can be assimilated to bribery. ...

Commercial Agents and Consultants: The Commission recognizes that corporations doing business abroad often engage the services of non-official nationals possessing specialized information with regard to business opportunities or relationships which are of assistance in securing or maintaining business. ... 
A variety of considerations, some legitimate and some questionable, may prompt the use of agents or consultants. ... Commission or consultant payments substantially in excess of the going rate for such services may give rise to a disclosable event, depending upon the significance of the business involved. In many instances, this may suggest that a portion of the commission was, in fact, intended to be passed through to government officials or their designees to influence government action. ...

Commercial Bribery: The Commission also has observed payments made to improperly influence a non-governmental customer's use of a company's product or services. ${ }^{70}$

Congress could have legislated as to the wide range of foreign corporate payments discovered. Indeed, certain of the bills introduced during the legislative process captured a wide range of foreign corporate payments. Yet in passing the FCPA, Congress intended to capture only a narrow range of foreign corporate payments. Congress's intent on these issues would seem directly linked to the primary foreign policy motivation it had in investigating the foreign corporate payments as well as recognition of the difficult and complex business conditions encountered in many foreign markets.

Senators Church and Proxmire were clear as to the scope of the law they envisioned. Senator Church stated as follows:

Let us be clear that we are not just talking about a little 'baksheesh' to grease the palm of some petty clerk in order to speed needed documents on their way through the bureaucratic labyrinth. What we are talking about is a concerted effort by the petroleum industry to buy favorable tax and energy legislation in a European country in which one U.S. company alone made over \$50 million in contributions to the government parties and members of the cabinet over a 9 year period. What we are talking about is an arms industry campaign to flood the Middle East with weapons, in which a U.S. aircraft company paid over $\$ 100$ million in agents' fees in one country to sell an airplane which has no competitor. A large part of that $\$ 100$ million is known to have ended up in the Swiss bank accounts of high military and civilian defense officials of the purchasing country. I could go on with other examples, but it suffices to say that what is at issue here is a massive and widespread perversion of the free enterprise system. ${ }^{71}$

\section{Senator Proxmire stated:}

I recognize it is hard [to define a bribe], but we are not concerned so much about the low level grease payments. What we are talking about is the payment, as I say, to make a sale ... . What we are concerned about, as I say, and trying to get at ... is bribery for the purpose of making sales abroad. 
[W]e define [a bribe] as a payment to an official of a foreign government for the purpose of inducing him to use his influence to secure business for the issuer or influence legislation or regulations of his government. ${ }^{72}$

Representatives Murphy and Eckhardt likewise stated during a House hearing: 'This bill is not concerned with so-called grease or facilitating payments, such as may be necessary to some petty clerk to speed documents through a bureaucracy. The bill does not address itself to "grease" or "facilitating" payments made to low-level clerical or ministerial government officials." 73

Senate and House Reports evidence the limited nature of the FCPA and that it would not capture all foreign corporate payments Congress learned of during its multi-year investigation.

A Senate Report stated:

In drafting the bill ... the Committee deliberately cast the language narrowly, in order to differentiate between such payments [to a foreign official corruptly intended to induce the recipient to use his influence to secure business, influence legislation or regulations] and low-level facilitating payments sometimes called 'grease payments.' Thus, [the bill] would not reach a small gratuity paid to expedite shipment through Customs or the placement of a trans-Atlantic telephone call, to secure required permits, or to ensure that a corporation's warehouses were not put to the torch. In other words, payments made to expedite the proper performance of duties may be reprehensible, but it does not appear feasible for the United States to attempt unilaterally to eradicate all such payments. However, where the payment is made to influence the placement of government contracts or to influence the formulation of legislation or regulations, such payment is prohibited ... . The Committee fully recognizes that the proposed law will not reach all corrupt payments overseas. ${ }^{74}$

\section{A House Report likewise stated:}

The scope ... is limited by the requirement that the offer, promise, authorization, payment, or gift must have as a purpose inducing the recipient to use influence with the foreign government or instrumentality, or to refrain from performing any official responsibilities, so as to direct business to any person, maintain an established business opportunity with any person, divert any business opportunity from any person or influence the enactment or promulgation of legislation or regulations of that government or instrumentality. ... The bill's coverage does not extend to so-called grease or facilitating payments. ... The language of the bill is deliberately cast in terms which differentiate between such payments and facilitating payments, sometimes called 'grease payments'. In using the word 'corruptly', the committee intends to distinguish between payments which cause an official to exercise other than his free will in acting or deciding or influencing an act or decision and those 
payments which merely move a particular matter toward an eventual act or decision or which do not involve any discretionary action. In defining 'foreign official', the committee emphasizes this crucial distinction by excluding from the definition of 'foreign official' government employees whose duties are essentially ministerial or clerical. For example, a gratuity paid to a customs official to speed the processing of a customs document would not be reached by the bill. Nor would it reach payments made to secure permits, licenses, or the expeditious performance of similar duties of an essentially ministerial or clerical nature which must of necessity by performed in any event. While payments made to assure or to speed the proper performance of a foreign official's duties may be reprehensible in the United States, the committee recognizes that they are not necessarily so viewed elsewhere in the world and that it is not feasible for the United States to attempt unilaterally to eradicate all such payments. As a result, the committee has not attempted to reach such payments. However, where the payment is made to influence the passage of law, regulations, the placement of government contracts, the formulation of policy or other discretionary governmental functions, such payments would be prohibited. The committee fully recognizes that the proposed law will not reach all corrupt payments overseas. ${ }^{75}$

As evident from the above legislative history, despite learning of a wide range of foreign corporate payments, Congress limited the FCPA's payment provisions to a narrow category of foreign recipients and further narrowed the range of actionable payments to those involving foreign government procurement or influencing foreign government legislation or regulations.

The FCPA also contained a limiting 'business purpose' test. The Conference Report stated:

The scope of the prohibition [in the Senate bill] was limited by the requirement that the offer, promise, authorization, payment, or gift must have as a purpose inducing the recipient to use his influence with the foreign government or instrumentality, influencing the enactment or promulgation of legislation or regulations of that government or instrumentality or refraining from performing any official responsibilities, so as to direct business to any person, maintain an established business opportunity with any person or divert a business opportunity from any person.

The House amendment was similar to the Senate bill; however, the scope of the House amendment was not limited by the 'business purpose' test [...] The conferees clarified the scope of the prohibition by requiring that the purpose of the payment must be to influence any act or decision of a foreign official (including a decision not to act) or to induce such official to use his influence to affect a government act or decision so as to assist an issuer in obtaining, retaining or directing business to any person. ${ }^{76}$ 
In short, despite learning of a wide range of foreign corporate payments to a variety of recipients and for a variety of reasons, Congress accepted in passing the FCPA to capture only a narrow range of such payments.

As discussed at the beginning of this chapter, the FCPA's legislative history is important in that it is a fruitful source of instruction as to the FCPA's proper interpretation. Understanding the FCPA's legislative history is thus not merely an interesting history lesson or academic exercise. Rather the rule of law demands an analysis of legislative history in giving meaning to the FCPA.

As you learn more about the FCPA's new era in the following chapters, your understanding of why Congress enacted the FCPA, and what Congress sought to capture in enacting the law, will give you an informed base to critically analyze this new era of enforcement. Your understanding of the FCPA's legislative history also highlights that many of the difficult and complex issues Congress confronted decades ago remain today.

\section{ENFORCEMENT BEGINS AND THE FCPA MATURES}

In analyzing this new era of FCPA enforcement, it is also important to understand how the FCPA was previously enforced and how the FCPA matured through its 1988 and 1998 amendments into its modern form.

This section profiles early FCPA enforcement actions and how certain of these actions foreshadowed difficult enforcement issues that remain in this new era. The level of enforcement for most of the FCPA's history was far less than it is today. In fact, the number of core corporate FCPA enforcement actions in a typical year in this new era exceeds the number of enforcement actions during a decade of early FCPA enforcement. This section will highlight various factors that explain this historical discrepancy including that the infant FCPA was widely viewed, even by the enforcement agencies, as an imprecise and confusing statute.

Despite its widely perceived deficiencies, reforming a law called the 'Foreign Corrupt Practices Act' was a political hot potato simply because of its name. Indeed early reform proposals included changing the name of the law so that a substantive, issue-based discussion could take place free from pro-bribery vs. anti-bribery rhetoric. This section will conclude by chronicling how the FCPA has matured as a statute into its modern form. 


\section{Early FCPA Enforcement}

Given the SEC's active role in helping to uncover many of the foreign corporate payment issues leading to the FCPA's enactment, it was not surprising that the first FCPA case was brought by the SEC.

In 1978, the SEC filed a civil injunctive action against Page Airways, Inc. and certain of its officers and directors alleging that the company and the individual defendants 'engaged in a scheme to sell Gulfstream II aircraft and other aircraft, products and services, by directly and indirectly, making payments to foreign government officials and employees and other corrupt, illegal, improper or unaccountable payments. ${ }^{77}$ Foreshadowing an issue that remains today - the lack of transparency in many FCPA enforcement actions - the SEC release noted: 'In reaching settlement of this action, the Commission and Page considered concerns raised by another agency of the United States Government regarding matters of national interest.'

The DOJ's first criminal FCPA enforcement action soon followed and it was filled with intrigue. In 1979, the DOJ charged postage stamp distributor Kenny International Corporation with violating the FCPA's anti-bribery provisions for engaging in a scheme to influence the Government of the Cook Islands to renew a stamp distribution agreement. ${ }^{78}$ The major players in the scheme were: Finbar Kenny (Chairman of the Board, President and majority shareholder of Kenny International); the Cook Islands Party (a foreign political party); and Sir Albert Henry (the Leader of the Cook Islands Party and the Premier of the Cook Islands).

The DOJ alleged that Kenny International could only be assured of renewal of the stamp distribution agreement by the continuation of the Cook Island Party's control of the Legislative Assembly and the retention of Sir Albert Henry as Premier. According to the DOJ, 'anticipating that the election would be closely contested, Sir Albert Henry and his fellow party officials determined that to guarantee their party's continued control in the Legislative Assembly it would be necessary to transport by air from New Zealand, a distance of approximately 1,800 miles, Cook Islands Party supporters to vote for them in the forthcoming election.'

Thereafter, the DOJ alleged that a personal representative of Sir Albert Henry and the Cook Islands Party solicited the financial assistance of Kenny and Kenny International to subsidize the air transportation costs of the Cook Island Party supporters. According to the DOJ, the defendants 'desiring the retention of Sir Albert Henry as Premier in order to insure the renewal of the stamp distribution agreement, agreed to provide the 
requested financial assistance upon the condition that Sir Albert Henry and the Cook Islands Party keep secret the source of the funds.'

A 1981 enforcement action against construction company Sam Wallace Company Inc. represented the first FCPA enforcement action involving both a DOJ and SEC component. ${ }^{79}$ The conduct at issue involved payments to the Chairman of the Trinidad and Tobago Racing Authority to obtain and retain a contract to construct buildings at a racetrack in Trinidad. The DOJ alleged that the company, aided and abetted by certain of its officers and employees, caused a wholly-owned subsidiary company to 'create fictitious purchase orders to purported suppliers ... for the purpose of concealing the withdrawal of corporate funds' in order to make payments to the official. Based on the same core set of conduct, the SEC also brought civil charges against the company and certain of its executives. According to the SEC's complaint, the defendants 'disguised and concealed [the] payments on Wallace's book and records by utilizing, or causing to be utilized, certain false accounting entries which did not reflect the true nature and purpose of, and falsely described the expenditures used in the making' of the payments to the official.

In 1982, the first FCPA mega-case was brought and it involved five corporate defendants and twelve individual defendants. The DOJ indictment charged a conspiracy between the defendants (companies and individuals in the oil and gas services industry) to pay approximately $\$ 10$ million to alleged Mexican foreign officials employed by Pemex, the national oil company wholly-owned by the Government of Mexico, and a third party 'knowing that all or a portion of such money' would be given to the official to induce the official to use his influence in order to assist the defendants in 'obtaining or retaining business with Pemex.' 80

According to the DOJ, as part of the conspiracy various defendants arranged with a third party who held itself out as the Mexican agent of a defendant company 'while in truth acting primarily as the conduit for the bribe payments.' The DOJ alleged that the third party disguised the bribe payments as 'commissions' by providing various defendants 'false and fictitious' invoices for each payment received. The indictment further alleged that the defendants used the term 'folks' as a code word for the 'foreign officials' 'in order to conceal from others the true identities [of the] officials and the existence of the bribe scheme.'

The companies involved all ultimately pleaded guilty and were ordered to pay fines ranging from approximately $\$ 3.5$ million to $\$ 5,000$. The individuals all pleaded guilty or nolo contendere.

All individuals, that is, except for George McLean (the former Vice President of Solar Turbines International, a division of International Harvester Company). Even though International Harvester pleaded guilty 
to conspiracy to violate the FCPA, McLean won pre-trial dismissal of substantive FCPA charges against him based on the so-called Eckhardt Amendment (an original provision in the FCPA that is no longer part of the statute which generally required that in order to prosecute an employee for a substantive FCPA offense, the corporate employer must first be convicted of similarly violating the FCPA) ${ }^{81}$ An appellate court, in rejecting the DOJ's appeal of the dismissal, concluded that 'both the language of the Act and its legislative history reveal a clear intent to impose criminal sanctions against the employee who acts at the behest of and for the benefit of his employer only where his employer has been convicted of similar FCPA violations. ${ }^{92}$

Despite dismissal of substantive FCPA charges, McLean still faced prosecution on charges of conspiracy to violate the FCPA. On this charge, McLean exercised his constitutional right to a jury trial and put the DOJ, for the first time in FCPA history, to its high burden of proof at trial. He prevailed as the jury found him not guilty. ${ }^{83}$ Even though McLean prevailed against the DOJ, his victory was not without costs. The thousands of hours he spent on his defense consumed his life and took him away from his young family, damaged his reputation, and changed his life forever.

In addition to the McLean matter, the DOJ also suffered FCPA defeats when put to its burden of proof in two other early FCPA enforcement actions.

In 1989, the DOJ criminally charged various individuals associated with AEA Aircraft Recovery (a company in the business of recovery of seized aircraft) including Alfredo Duran. ${ }^{84}$ According to the charging documents, the various defendants conspired to make payments to officials of the Dominican Republic in order to obtain the release of two aircraft seized by the government. All of the defendants pleaded guilty except for Duran (a former Florida political leader) who pleaded not guilty and put the DOJ to its high burden of proof at trial. After the DOJ presented its evidence at trial, Duran filed a motion for judgment of acquittal and argued that 'no reasonable jury could find that the purpose of any of the alleged intended payments was to assist [...] in obtaining or retaining business' and that the government 'has failed to adduce sufficient evidence to prove any intended payments were not facilitating or expediting payments for the purpose of expediting or securing routine governmental action (i.e. grease payments).' The trial court judge granted a judgment of acquittal ending the case. According to media reports, in granting the acquittal, the judge said that 'the government failed to prove the charges against [Duran] were a crime under the FCPA.' 
In 1990, the DOJ criminally charged Harris Corporation (a company that manufactured telephone switching systems) and two executives, John Iacobucci and Ronald Schultz, with conspiracy to violate the FCPA. ${ }^{85}$ According to the charging documents, the defendants paid and authorized the payment of money to a third party 'while knowing that a portion of such money' would be offered or given, directly or indirectly, to officials of the Government of Colombia in order to influence the officials to award government telecommunications contracts to Harris. According to the indictment, pursuant to the conspiracy Harris retained an agent based upon representations that he had connections with officials in the government that he would use to assist Harris in obtaining telecommunications contracts.

Upon filing of the criminal charges, the Chairman and CEO of Harris stated: 'We believe that these charges are based upon a distorted view of the facts, and they represent a radical departure from existing enforcement policies. We have cooperated fully with the DOJ in its investigation of the allegations, providing clear evidence refuting the charges.'

The company, along with the individuals, put the DOJ to its high burden of proof at trial. In 1991, the trial court judge granted a motion for judgment of acquittal. Media reports stated:

Shortly after the government rested its case, [the trial court judge] ruled from the bench that 'no reasonable jury' could convict the company nor its executives on any of the five bribery-related counts for which they were indicted. Citing insufficient evidence, [the judge] said the government had failed to show any intent by the defendants to enter into a criminal conspiracy. [The judge] also said it was the first time in his six years on the federal bench that he had dismissed a criminal case at mid-trial for lack of evidence.

After the judgment of acquittal, the Chairman and CEO of Harris stated:

We're very pleased that [we] have been vindicated, but we believe the charges should never have been brought in the first place. The DOJ's case was based upon a distorted view of the facts and represented a radical departure from existing enforcement policies. As a result, American taxpayers have been burdened with unnecessary litigation costs, and Harris has incurred more than $\$ 3$ million in legal fees, spent many hundreds of hours of our people's time, and suffered a substantial disruption of the corporation's business to prove an absence of wrongdoing that should have been apparent from the beginning. The case has also placed a heavy strain on our two employees named in the indictment.

The DOJ's early defeats when put to its high burden of proof in FCPA enforcement actions foreshadow an issue that remains in this new era of 
FCPA enforcement as detailed in Chapter 5. That is, while enforcement agencies have had 'success' in exercising their leverage and securing large corporate FCPA settlements through resolution vehicles not subjected to any meaningful judicial scrutiny, when put to its burdens of proof in the context of an adversarial system, the enforcement agencies have substantially less success. In a legal system founded on the rule of law, this latter form of success is more meaningful than the former.

Regardless of wins and losses, early FCPA enforcement was less robust than in this new era of enforcement. Indeed, between 1977 and 1987, there were approximately ten core corporate FCPA enforcement actions and between 1988 and 1998 there were approximately fifteen core corporate actions. By comparison, in this new era of FCPA enforcement, when corporate compliance practices far exceed those of the past, there are approximately ten to fifteen core corporate FCPA enforcement actions per year and Chapter 6 will explore certain practical and provocative reasons for the increase in FCPA enforcement.

However, it is generally futile to draw many meaningful conclusions from early FCPA enforcement or compare it to enforcement in this new era. For starters, growing pains associated with a new law, and a pioneering one at that, were understandable as both business organizations and enforcement agencies alike were absorbing the law and its new expectations and challenges. For example, two years into enforcing the FCPA, the DOJ Assistant Attorney General stated: 'The interpretive questions arising under the Act depend on subtle judgments of fact and law. We're dealing with a new Act, where no one has much enforcement experience. It is an Act that presents questions there has never been occasion to address in domestic bribery law .... ${ }^{86}$

Indeed, part of the reason for the general lack of early FCPA enforcement was that even the enforcement agencies viewed the FCPA as an imprecise and confusing statute. For instance, the new SEC Director of Enforcement stated in 1981 that he 'pledged to enforce, with discretion, the FCPA, which he criticized as being ambiguous. ${ }^{87}$ Among other ambiguities, the FCPA as originally enacted had an imprecise "while knowing or having reason to know' standard applicable to liability for the conduct of third parties such as foreign agents. During FCPA reform hearings in the 1980s the DOJ Deputy Attorney General stated:

The DOJ is sensitive to the unnecessary problems that the American business community has encountered in its attempts to interpret and apply the "reason to know' standard. We also know it is difficult to define exactly what constitutes 'reason to know.' For that reason, the policy of the Department has been to prosecute only those cases where the evidence of awareness - whether 
direct or circumstantial - was so clear as to constitute actual knowledge of the bribe scheme. ${ }^{88}$

The DOJ Assistant Attorney General likewise stated during Congressional hearings that the then standard for third-party liability was akin to a 'simple negligence standard' and 'is plainly inappropriate and inconsistent with the general approach of modern criminal law to state-of-mind requirements. ${ }^{89}$ The U.S. Trade Representative was more blunt when describing this standard and said 'frankly, nobody knows what it means. ${ }^{90}$

While Chapter 6 specifically discusses the reasons for the increase in FCPA enforcement in this new era, for present purposes it is useful to note that for much of the FCPA's history there were material differences in the law, enforcement agency policies, and the global business environment that all impacted early FCPA enforcement. For instance, fewer persons (both legal and natural) were subject to the FCPA for much of its history compared to now. When the FCPA became law in 1977 few foreign companies had shares listed on a U.S. exchange. As you will learn in Chapters 3 and 4, such a listing makes a company an 'issuer' and thus subject to the FCPA. By comparison, there are now approximately 1,000 foreign companies with shares listed on a U.S. exchange and thus subject to the FCPA. ${ }^{91}$ In addition, in 1998 the FCPA was amended so that certain other foreign companies and foreign nationals could become subject to the FCPA under certain conditions. Furthermore, the resolution vehicles available to the enforcement agencies for much of the FCPA's history were materially different compared to today. For most of the FCPA's history, the DOJ only had two options upon learning of conduct that potentially violated the FCPA: charge the company or do not charge the company. As discussed in greater detail in Chapter 2, in 2004 the DOJ began using alternative resolution vehicles such as NPAs and DPAs to resolve FCPA enforcement actions, and use of these vehicles has unquestionably resulted in more FCPA enforcement actions.

Nor can any meaningful conclusions be drawn from comparing fine and penalty amounts in early FCPA enforcement actions to fine and penalty amounts in this new era. For starters, the FCPA's statutory fine and penalty amounts have changed over time. Perhaps more significantly, you will learn in Chapter 5 that criminal fine amounts in FCPA enforcement actions are rarely based on the statutory amounts, but rather based on the Alternative Fines Act, a statute passed in 2006, which can result in a fine amount up to twice the benefit the payer sought to obtain through the improper payment. ${ }^{92}$ Moreover, it was not until 1990 that the SEC was given authority to assess civil monetary penalties in a wide 
variety of securities law enforcement actions including FCPA enforcement actions. ${ }^{93}$ In addition, disgorgement, a central feature of most SEC FCPA enforcement actions in this new era, was not yet used in SEC enforcement actions.

Although certain historical comparisons of FCPA enforcement lack meaningful value, other comparisons are noteworthy. While one can question how the enforcement agencies held individuals accountable (i.e. criminal v. civil charges) during the early years of FCPA enforcement, the enforcement agencies did frequently hold individuals accountable when a company resolved an FCPA enforcement action. Indeed, during the FCPA's first decade, approximately 90 percent of corporate FCPA enforcements also resulted in related charges against company employees. This is a meaningful statistic and stands in stark contrast to this new era in which approximately 70 percent of corporate FCPA enforcement actions have not resulted in any charges against company employees. This FCPA enforcement statistic, as well as many others relevant to corporate and individual FCPA enforcement actions, are highlighted in greater detail in Chapter 5.

\section{The FCPA's 1988 and 1998 Amendments}

Against the background of early FCPA enforcement is perhaps the more important issue that while the FCPA was indeed a pioneering and valuable statute it was widely viewed as an imperfect statute. Indeed, almost as soon as the FCPA was passed in 1977 concerns were raised across a wide spectrum that the law was vague and ambiguous, and because of that, harmful to U.S. businesses seeking to compete in the global marketplace. The early 1980s saw much FCPA reform activity. In 1980, the Carter administration (recall that President Carter signed the FCPA into law in 1977) sent a report to Congress prepared by the Secretary of Commerce and the U.S. Trade Representative titled 'Report of the President on Export Promotion Functions and Potential Export Disincentives. ${ }^{94}$ In pertinent part, the report stated:

The [FCPA] is identified by businessmen and attorneys as one of the most significant export disincentives. [...] The Act inhibits exporting because of uncertainty within the business community about the meaning and application of some of its key provisions.

Uncertainty about the meaning of key provisions of the FCPA and how it will be applied is having a negative effect on U.S. exports. Many of the businessmen and attorneys consulted expressed the view that this uncertainty has a far greater impact than the actual prohibition against bribery. The problem described, in essence, is that what conduct is prohibited and what 
conduct is not prohibited under the Act is often unclear. In order to avoid possible violations of the Act, attorneys often give such cautious guidance that their clients simply forego any transactions where the FCPA could possibly become an issue.

The effects of these uncertainties reportedly manifest themselves in various ways. Consultations with the private sector revealed instances in which U.S. companies: withdrew from joint ventures for fear they later could be held responsible for the acts of their foreign partners; incurred substantial legal and investigative costs to check the backgrounds of their sales agents abroad; were unable to obtain the services of effective sales agents; lost contracts simply because of the time needed to investigate sales agents abroad and institute safeguards; withdrew from existing markets; and declined to enter new markets.

Finally, companies point out that the extent to which companies have been successfully prosecuted under the FCPA does not define the extent of the disincentive. Uncertainty can be a disincentive without any prosecutions and, moreover, exports are inhibited merely by the possibility of public charges and the adverse publicity surrounding them. Even where a company is totally convinced that a court would find that it had not violated the FCPA, it nonetheless may forego the export opportunity for fear that an enforcement agency could publicly charge it with a violation of the Act.

In 1981, the Government Accounting Office ('GAO'), the investigative arm of Congress, released a report titled 'Impact of Foreign Corrupt Practices Act on U.S. Business.' 95 The report was based in part on a GAO questionnaire survey of 250 companies randomly selected from the Fortune 1000 list of the largest industrial firms in the U.S. and the questionnaire addressed the FCPA's relationship to the following four areas: (1) corporate policies and/or codes of conduct; (2) corporate systems of accountability; (3) cost burdens, if any, incurred by management to comply with the FCPA; and (4) corporate opinions regarding the: (i) FCPA's effect on U.S. corporate foreign sales; (ii) the clarity of the FCPA's provisions; (iii) the potential effectiveness of an international anti-bribery agreement; and (iv) perceived effectiveness of the FCPA in reducing questionable payments.

The GAO found that while the FCPA 'has brought about efforts to strengthen corporate codes of conduct and systems of internal accounting control,' corporations reported that 'their efforts to comply with the [the FCPA] have resulted in costs that were greater than the benefits received' and that a substantial number of businesses 'reported that they had lost oversees business as a result' of the FCPA. The GAO report noted concerns that the FCPA's anti-bribery provisions were 'vague and ambiguous' and stated that while 'unambiguous requirements may be 
impractical and could provide a roadmap for corporate bribery' companies operating in the global marketplace 'should be subject to clear and consistent demands by the Government agencies for enforcing the act.'

Despite its widely perceived deficiencies, reforming a law called the 'Foreign Corrupt Practices Act' was a political hot potato simply because of the name of the law. Indeed early FCPA reform proposals included changing the name of the law so that a substantive, issue-based discussion could take place free from pro-bribery vs. anti-bribery rhetoric. For instance, among the first FCPA reform bills introduced in 1980 was the 'Business Accounting and Foreign Trade Simplification Act' which sought to change the name of the FCPA as well as other substantive changes. ${ }^{96}$ The preamble of the bill stated, in pertinent part, as follows.

The principal objectives of the [FCPA] are desirable, beneficial, and important to our Nation as well as to our relationships with our trading partners, and these objectives should remain the central intent of the [FCPA];

exporters should not be subject to unclear, conflicting, and potentially damaging demands by diverse United States agencies responsible for enforcement of the [FCPA];

legal interpretations and general compliance and enforcement practices associated with the [FCPA] should be developed in accordance with considerations underlying foreign policy relations, international trade, export promotion, international monetary policy, and other related civil and criminal statutes;

However, the mere discussion of FCPA reform was opposed by some who seemed to advance the simplistic - either you are against bribery or for bribery - position. Despite this political atmosphere, certain Congressional leaders demonstrated courage to reform the FCPA into a better, more useable statute for business and the enforcement agencies alike.

For instance, in 1981 Senator Alfonse D'Amato opened Senate hearings on an FCPA reform bill by stating:

The discussion which takes place during these hearings is not a debate between those who oppose bribery and those who support it. I see the major issue before us to be whether the law, including both its anti-bribery and accounting provisions, is the best approach, or whether it has created unnecessary costs and burdens out of proportion to the purposes for which it was enacted, and whether it serves our national interests. ${ }^{97}$

Senator John Chafee stated: 
Critics have attempted to characterize my bill as a signal to U.S. companies that they can return to the 'bad old days' of foreign bribery. That is not my intent, nor should it be the signal. I abhor bribery, whether domestic or foreign, but I also dislike confusion. Thus, my bill will eliminate uncertainty while maintaining strong prohibitions against bribery. The ambiguities and murkiness of the bill's language have caused U.S. companies to withdraw from legitimate markets and contributed to the decline in the U.S. share of world exports. We need to end this confusion. ${ }^{98}$

\section{During the hearing, Senator D'Amato also noted:}

The thing that bothers me about this kind of a debate is that we tend to posture this thing as if somebody were for or against bribery. I think it is important to state for the record that bribery of any foreign official by any U.S. concern is bad for our national health, and it is something that we have got to stop, we have got to deal with, and we have, I think, gone a long way with the FCPA. What we proposed to do is to simplify that law and to make it workable so that we can set that standard in concrete from now on and not have the abuses that occurred prior to 1977, but not by stopping exports, but by stopping bribery. That is the objective. [...] I think it is very important that in the committee's work that we not create the attitude that this committee is making it easier for businesses to engage in illegal activity. [...] I think that rather than hampering prosecution of illegal acts, [the reform bill at issue] would clarify and make possible just prosecution of those who engage in bribery. It would eliminate any 'gray area' by clearly spelling out the limits of the law. ${ }^{99}$

\section{During the hearing, Senator John Heinz stated:}

There are many people that are extremist, and there are others who get carried away by their enthusiasm who are going to argue that even if we change the provisions in the present act, that are unnecessary or ambiguous or uncertain, that even though we are not doing so, we are legalizing bribery. That strikes me as the worst kind of demagoguery, because it implies that everything that Congress has done in the past is perfect. And does anybody believe that? ${ }^{100}$

\section{As the U.S. Trade Representative stated:}

Just because the FCPA spotlights a sensitive subject, some people wish to turn a 'blind eye' to its shortcomings rather than risk being accused of being 'soft on bribery.' That is too easy a way out. Retreating from controversy will not cure the law's deficiencies. [...] Is there any U.S. law that ought to be above such review and clarification - especially one as complex as the FCPA? ${ }^{101}$

Indicative of the political challenges of reforming a law called the Foreign Corrupt Practices Act, FCPA reform took eight years and it is 
noteworthy how it occurred. In 1988 the FCPA was amended, not through a stand-alone bill, but through Title V, Subtitle A, Part I of the Omnibus Trade and Competiveness Act of 1988 signed into law by President Ronald Reagan. ${ }^{102}$

Principle changes to the FCPA in 1988 included: (i) amending the original 'reason to know' standard applicable to third-party liability; (ii) amending the FCPA to include certain affirmative defenses based on foreign law and reasonable and bona fide expenditures; and (iii) amending the FCPA to include an express facilitating payment exception. As to this later change, the FCPA's original definition of 'foreign official' contained an indirect facilitating payment exception by excluding from the definition of 'foreign official' 'any employee of a foreign government or any department, agency, or instrumentality thereof whose duties are essentially ministerial or clerical.' The effect of the 1988 amendments was to remove this indirect exception from the definition of foreign official in favor of an express stand-alone exception for 'routine governmental action.'

Issues related to third-party payments, the facilitating payments exception and the FCPA's affirmative defenses are discussed in greater detail in Chapter 3.

In 1998 the FCPA was further amended to incorporate certain aspects of the Organization for Economic Cooperation and Development ('OECD') Convention on Combating Bribery of Foreign Public Officials in International Business Transactions (the 'OECD Convention') signed by the U.S. and approximately thirty other countries in $1997 .{ }^{103}$ Principle changes to the FCPA in 1998 included: (i) the creation of a new statutory provision applicable to certain foreign companies and foreign nationals; and (ii) expanded nationality jurisdiction as to U.S. companies and citizens by which the anti-bribery provisions can apply regardless of whether an improper payment scheme has a U.S. territorial nexus. These issues are likewise discussed in greater detail in Chapter 3.

\section{NOTES}

1. Flora v. U.S., 362 U.S. 145 (1960).

2. U.S. v. McLean, 738 F.2d 655 (5th Cir. 1984).

3. U.S. v. Kay, 359 F.3d 738 (5th Cir. 2004).

4. James Doty, 'Toward a Reg. FCPA: A Modest Proposal for Change in Administering the Foreign Corrupt Practices Act,' The Business Lawyer (Aug. 2007).

5. FCPA Professor, 'The FCPA as an Ambiguous Statute and the Importance of Legislative History' (Feb. 13, 2013).

6. See, e.g., Lewis v. Spork, 612 F.Supp. 1316 (N.D. Cal. 1985). 
7. SEC, 'Report of the Securities and Exchange Commission on Questionable and Illegal Corporate Payments and Practices,' (1976), reprinted in Special Supplement, Sec. Reg. \& L. Rep. (BNA) No. 353 (May 19, 1976).

8. Multinational Corporations and United States Foreign Policy: Hearings before the Subcomm. on Multinational Corps. of the S. Comm. on Foreign Relations, 94th Cong. 1 (1975).

9. Foreign Payments Disclosure: Hearings before the Subcomm. on Consumer Prot. and Fin. of the H. Comm. on Interstate and Foreign Commerce, 94th Cong. 2 (1976).

10. The Activities of American Multinational Corporations Abroad: Hearings before the Subcomm. on Int'l Econ. Policy of the H. Comm. on Int'l Relations, 94th Cong. (1975).

11. Foreign Payments Disclosure: Hearings before the Subcomm. on Consumer Prot. and Fin. of the H. Comm. on Interstate and Foreign Commerce, 94th Cong. (1976).

12. Protecting the Ability of the United States to Trade Abroad: Hearings before the Subcomm. on Int'1 Trade of the S. Comm. on Fin., 94th Cong. (1975).

13. Supra note 10.

14. Supra note 12 .

15. 122 Cong. Rec. S6515-16 (1976) (daily ed. May 5, 1976).

16. Unlawful Corporate Payments Act of 1977: Hearings before the Subcomm. of Consumer Prot. and Fin. of the H. Comm. on Interstate and Foreign Commerce, 95th Cong. (1977).

17. Supra note 10.

18. Lockheed Bribery: Hearings before the S. Comm on Banking, Housing, and Urban Affairs, 94th Cong. (1975).

19. Id.

20. S. Rep. No. 94-1031, at 3 (1976).

21. Supra note 12.

22. Foreign Corrupt Practices and Domestic and Foreign Investment Disclosure: Hearing before the S. Comm on Banking, Housing, and Urban Affairs, 95th Cong. (1977).

23. Supra note 10.

24. S. Rep. No. 94-1031, at 4 (1976).

25. Foreign and Corporate Bribes: Hearings before the S. Comm. on Banking, Housing, and Urban Affairs, 94th Cong. (1976).

26. Supra note 10.

27. Supra note 25.

28. Id.

29. Supra note 10 .

30. Id.

31. Prohibiting Bribes to Foreign Officials: Hearing before the S. Comm. on Banking, Housing, and Urban Affairs, 94th Cong. (1976).

32. Supra note 10.

33. Supra note 31.

34. Supra note 10.

35. Id.

36. Id.

37. Supra note 18.

38. Corporate Business Practices and United States Foreign Policy: Hearing before the Subcomm. on Int'l Econ. Policy and Trade of the H. Comm. on Int'l Relations, 95th Cong. (1977).

39. Supra note 10. 
40. Supra note 18 .

41. Abuses of Corporate Power: Hearings before the Subcomm. on Priorities and Econ. in Gov't of the Joint Econ. Comm., 94th Cong. (1976).

42. 122 Cong. Rec. S15857 (1976) (daily ed. Sept. 15, 1976).

43. Supra note 10.

44. Id.

45. Supra note 25.

46. 94 Cong. Rec. S6516 (1976).

47. Supra note 25 .

48. Id.

49. Supra note 10.

50. Supra note 22.

51. Supra note 12.

52. Supra note 16.

53. Id.

54. Supra note 25.

55. Gerald R. Ford, 'Memorandum Establishing the Task Force on Questionable Corporate Payments Abroad' (Mar. 31, 1976).

56. Supra note 31.

57. Gerald R. Ford, Remarks Announcing New Initiatives for the Task Force on Questionable Corporate Payments Abroad (June 14, 1976).

58. Gerald R. Ford, Special Message to the Congress Transmitting Proposed Foreign Payments Disclosure Legislation (Aug. 3, 1976).

59. Supra note 22 .

60. Id.

61. S. Rep. No. 94-103 (1976).

62. 122 Cong. Rec. 30,337 (1976) (daily ed. Sept. 14, 1976).

63. Supra note 16.

64. Supra note 22.

65. S. Rep. No. 93-114, at 10 (1977).

66. H.R. Rep. No. 95-640, at 6 (1977).

67. Supra note 38.

68. 123 Cong. Rec. 38,778 (1977).

69. Presidential Statement on Signing the Foreign Corrupt Practices and Investment Disclosure Bill, 13 Weekly Compilation of Presidential Documents 1909 (Dec. 20, 1977).

70. Supra note 7.

71. Supra note 12.

72. Supra note 25.

73. Supra note 22.

74. S. Rep. No. 94-1031 (1976).

75. H.R. Rep. No. 95-640 (1977).

76. H.R. Rep. No. 95-831 (1977).

77. FCPA Professor, 'The FCPA's First Compliance Monitor' (Aug. 26, 2011), containing links to original source documents.

78. FCPA Professor, 'Postage Stamps, Sir Albert Henry, Flying Voters, and the FCPA' (Aug. 24, 2011), containing links to original source documents.

79. FCPA Professor, 'Bribery at the Racetrack' (Nov. 11, 2011), containing links to original source documents.

80. FCPA Professor, 'The FCPA's First Mega Enforcement Action' (Mar. 18, 2013), containing links to original source documents.

81. FCPA Professor, 'Looking Back on the Eckhardt Amendment' (Mar. 19, 2013).

82. 738 F.2d 655 (5th Cir. 1984). 
83. FCPA Professor, 'George McLean' (Mar. 20, 21, 2013).

84. FCPA Professor, 'An Important FCPA Case You've Likely Never Heard about' (May 7, 2012), containing links to original source documents.

85. FCPA Professor, 'One Win, One Loss' (May 16, 2011), containing links to original source documents.

86. 'Justice Outlines Priorities in Prosecuting Violations of For. Corrupt Practices Act,' The American Banker (Nov. 21, 1979).

87. Owen Ullmann, 'Corporate Lawyer Gets SEC Enforcement Post,' Associated Press (June 29, 1981).

88. Joint Hearing before the Subcommittee on International Finance and Monetary Policy and the Subcommittee on Banking, Housing, and Urban Affairs (June 10, 1986).

89. 'The Foreign Trade Practices Act,' Hearings before the Subcommittee on International Economic Policy and Trade of the Committee on Foreign Affairs, House of Representatives (1983).

90. Id.

91. SEC, 'Number of Foreign Companies Registered and Reporting with the U.S. Securities and Exchange Commission' (Dec. 31, 2010).

92. 18 U.S.C. $\$ 3571$.

93. Securities Enforcement Remedies and Penny Stock Reform Act of 1990. Pub. L. 101-429 (Oct. 15, 1990).

94. 'Report of the President on Export Promotion Functions and Potential Export Disincentives: Together with the Review of Executive Branch Export Promotion Functions and Potential Export Disincentives,' Transmitted to the Congress (Sept. 1980).

95. By the Comptroller General, Report to the Congress of the United States, 'Impact of the Foreign Corrupt Practices Act on U.S. Business,' (Mar. 1981).

96. S. 2763 (introduced May 28, 1980).

97. Joint Hearings before the Subcommittee on Securities and the Subcommittee on International Finance and Monetary Policy of the Committee on Banking, Housing, and Urban Affairs, U.S. Senate, 97th Cong. (May 20, 1981).

98. Id.

99. Id.

100. Id.

101. Id.

102. Public Law 100-418 (1988).

103. Public Law 105-366 (1998). 